\title{
Recent hydrologic change in a Colorado alpine basin: an indicator of permafrost thaw?
}

\author{
Nel CAINE \\ Institute of Arctic and Alpine Research, UCB 450 University of Colorado at Boulder, Boulder, CO 80309-0450, USA \\ E-mail: cainen@colorado.edu
}

\begin{abstract}
Hydrologic and hydrochemical studies have been conducted in Green Lakes Valley, Colorado Front Range, USA, above $3550 \mathrm{~m}$ since 1982. They show a classic seasonal hydrograph dominated by snowmelt and an earlier date for the start of spring flow and for peak flow over the period of record. This is consistent with patterns found at lower elevations in Colorado and throughout western North America. They also show an increasing trend in flows in September and October of $2.6 \pm 0.7 \mathrm{~mm} \mathrm{a}^{-1}$ which is not found elsewhere and cannot be accounted for by increased autumn precipitation and the melting of surface ice. Because this late-season increase is not found at the highest elevations or in basins in which there is no evidence of permafrost, it seems best explained by the thawing of alpine permafrost at intermediate elevations. This is corroborated by an increase in the concentration of base cations and silica, and particularly in $\mathrm{Ca}^{2+}$ and $\mathrm{SO}_{4}{ }^{-}$, in the stream discharge starting in 2000. As with the physical hydrology, the geochemical signals have not been detected at the higher elevations in the basin, though they have previously been associated with streamflow from a small rock glacier in the valley. The combined evidence suggests the degradation of ice-rich permafrost on the north-facing slopes of the valley below $3700 \mathrm{~m}$, where it has been detected at $3 \mathrm{~m}$ depth by geophysical surveys.
\end{abstract}

\section{INTRODUCTION}

The impact of permafrost degradation on water quality, nutrient discharge from river basins and hillslope stability has recently received attention in polar environments where atmospheric warming has been documented (e.g. Gooseff and others, 2009; Keller and others, 2010; Rowland and others, 2010). The potential for permafrost thaw in high mountain environments has drawn less attention (Harris and others, 2009), most often in the context of concerns over rock-wall instability (e.g. Fischer and others, 2006; Huggel and others, 2010) or water resources (Azócar and Brenning, 2010), although it also has the potential to influence nutrient and organic exports from alpine basins (e.g. Hood and others, 2003; Williams and others, 2007).

In the southern Rocky Mountains, USA, where there is relatively little infrastructure at high elevations and where the active layer over sporadic permafrost seems to be up to $3 \mathrm{~m}$ thick (Ives, 1973; Leopold and others, in press), the implications of potential permafrost thaw have received much less attention. However, with permafrost likely above $3500 \mathrm{~m}$ elevation (Janke 2005), the question of its response to environmental change remains. Here, the temporal signals in two datasets (late-season streamflows and the geochemistry of surface water at that season) are evaluated. They suggest that in a high alpine basin of the Colorado Front Range melting of permafrost has occurred and has contributed to recent increases in autumn streamflows.

\section{FIELD SITE AND DATA}

Above 3200 m, Green Lakes Valley (Fig. 1) is a $7.1 \mathrm{~km}^{2}$ alpine basin (Caine, 2001). It includes two contrasting sections: (1) the upper basin $\left(2.1 \mathrm{~km}^{2}\right)$ comprising the area draining through Green Lake 4 at $3500 \mathrm{~m}$; and (2) the lower valley $\left(5.0 \mathrm{~km}^{2}\right)$ between Green Lake 4 and the former mining camp of Albion. The upper valley is a high alpine environment with about $20 \%$ vegetation cover, steep rock walls, talus slopes and a valley floor of glacially smoothed bedrock. The lower valley has less exposed bedrock, fewer cliff-talus slopes and a more extensive soil and vegetation cover (including about $0.4 \mathrm{~km}^{2}$ of forest on the south-facing valley side). A $90 \mathrm{~m}$ high valley step between Green Lakes 3 and 4 separates the two valley sections. Most of the basin is underlain by granodiorites and quartz monzonite. Precambrian gneisses and metasediments are exposed on the northern slopes of Kiowa Peak and around Green Lake 5 (Fig. 1).

The distribution of alpine permafrost in Green Lakes Valley has been mapped by Janke (2005) on the basis of vegetation patterns, surface forms, climate records and surveys of the basal temperature of the winter snow cover. The results suggest that about $85 \%$ of the upper Green Lakes Valley may be underlain by permafrost. This supports the early report by Ives (1973) of permafrost below an active layer of $3-5 \mathrm{~m}$ thickness on Niwot Ridge (Fig. 1), the northern boundary of the basin, and has been corroborated by geophysical surveys on the north-facing slopes of the valley (Leopold and others, in press).

Hydrological studies have been conducted in the Green Lakes Valley as part of a Long-Term Ecological Research (LTER) program since 1982 and were summarized in Williams and Caine (2001). (The flow records are available at http://culter.colorado.edu/exec/nwtdatas.cgi.) For 19822009, mean annual flows at Green Lake 4 were 953 mm, with a non-significant upward trend of 4.7 with standard error $\mathrm{SE}=3.6 \mathrm{~mm} \mathrm{a}^{-1}$. The seasonal flows show a classic snowmelt hydrograph, with flows rising in May to a peak in late June and then declining into the autumn. They also suggest that the start of rising flows and the timing of peak flows have both tended to occur earlier in the season over the last 30 years (Fig. 2). This is consistent with hydrograph changes recorded at lower elevations elsewhere in Colorado (Clow, 2010) and across much of western North America (Stewart and others, 2004, 2005), though the rate of change suggested by Figure 2 seems greater than those at lower elevations. 


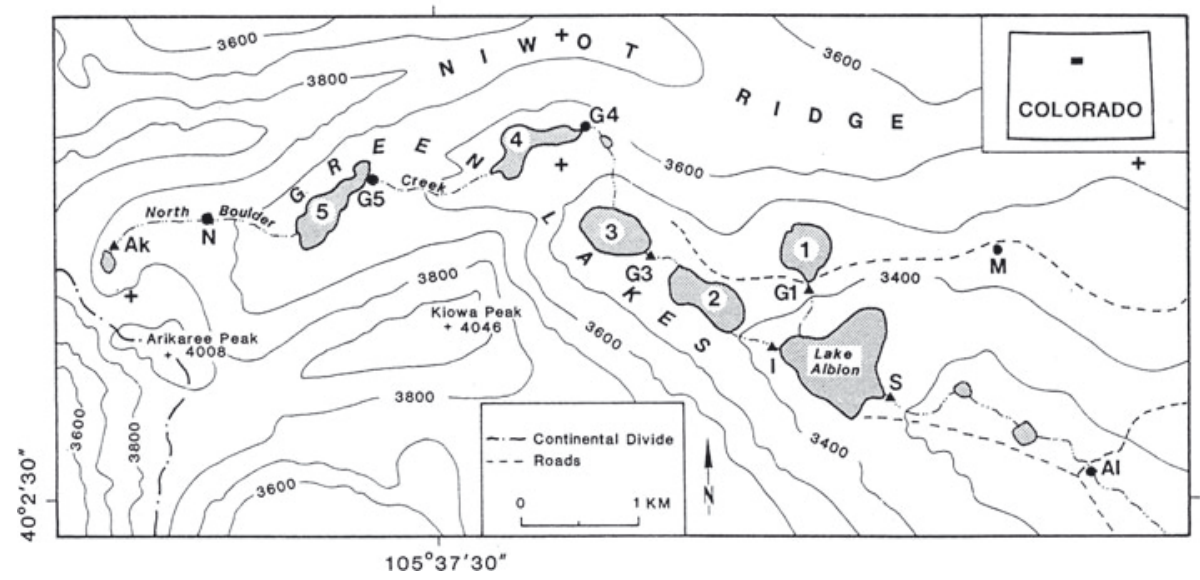

Fig. 1. Green Lakes Valley, Colorado, USA. Contour interval $200 \mathrm{~m}$. Study sites with a continuous discharge record (circles), other geochemical sampling sites (triangles) and climate stations (crosses) are shown. Site identification: Ak, Arikaree Glacier; N, Navajo; G5, Green Lake 5; G4, Green Lake 4; M, Martinelli; Al, Albion.

Here the hydrologic and hydrochemical records from three sites along the main stream of the upper Green Lakes are considered: Green Lake 4 (G4), Green Lake 5 (G5) and Navajo (N) (Fig. 1). At these sites, seasonal flow records (usually May-October) have been maintained from 1982 to 2009. These records are supported by equivalent records from five sites in the lower part of the valley: Lake Albion inlet (I), Lake Albion spillway (S), Green Lake 1 (G1), Martinelli (M) and Albion (Al) (Fig. 1). The last of these defines the surface discharge from the entire basin, to which the other sites are tributary. Estimated streamflows at these sites are usually based on records of water level at $10 \mathrm{~min}$ (or less) intervals that are converted to volume discharges by empirical ratings for each channel. Individual flow estimates are subject to errors of $\pm 10 \%$, but the monthly or longer averages used here should provide relatively better estimates. Stream hydrochemistry records are based on weekly or biweekly sampling during summer and autumn. During November-May, stream sampling has been less frequent, but these records are not used here. Chemical analysis has been conducted in the Kiowa Laboratory (Institute of Arctic and Alpine Research, Boulder, CO) and followed the procedures described by Williams and others (2006). Analytical procedures (including estimates of precision) are available at http://snobear.colorado.edu/Seiboldc/kiowa.html.

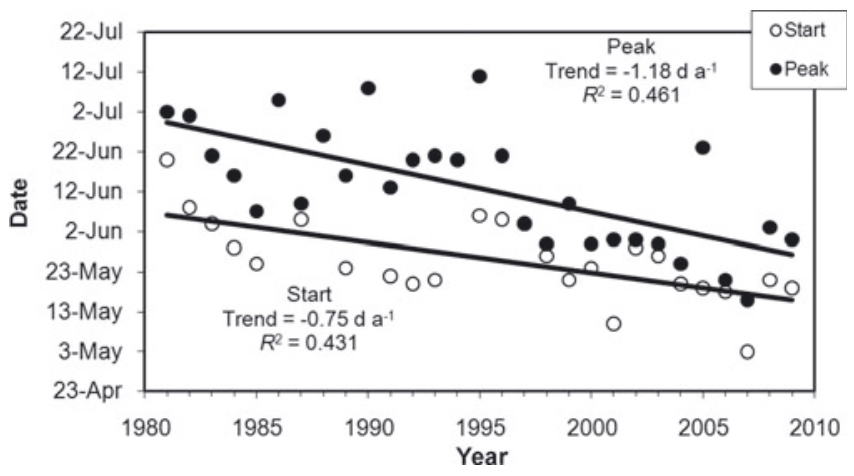

Fig. 2. Hydrograph changes at Green Lake 4, 1982-2009. The dates of the start of the spring rise in flows and of the annual peak flows are shown.

\section{SEPTEMBER-OCTOBER STREAMFLOWS}

Late-season flows at Green Lake 4 show a marked increase over the last three decades, for which there are records (Fig. 3; Table 1). An increase of $2.6 \mathrm{~mm} \mathrm{a}^{-1}\left(\mathrm{SE}=0.7 \mathrm{~mm} \mathrm{a}^{-1}\right)$ at Green Lake 4 is indicated during September and October. This is also reflected in the records at two other sites on the main channel draining the Green Lakes Valley: Green Lake 5 and Albion (Table 1). In contrast, the smaller drainage basins at Martinelli, on the south slope of Niwot Ridge, and Navajo, at the head of the valley, show no change in SeptemberOctober flows (Table 1). The decline in late-season flows at Martinelli is influenced by a record that includes five years in the last decade when flows ceased before 31 August. By comparison, in only one of the previous 18 years did flows end by 31 August. The Martinelli basin does not appear to be underlain by permafrost (Leopold and others, 2008) and is shown by Janke (2005) to have only a low probability of permafrost. In contrast, late-season flows at Navajo are maintained by ablation on Arikaree Glacier which occupies $0.09 \mathrm{~km}^{2}$ (about 25\%) of its catchment area.

At lower elevations in this part of the Front Range, the pattern of increasing September-October flows is not evident in the larger and lower basin of Middle Boulder Creek at Nederland (about $10 \mathrm{~km}$ southeast of Green Lakes Valley) (Table 1).

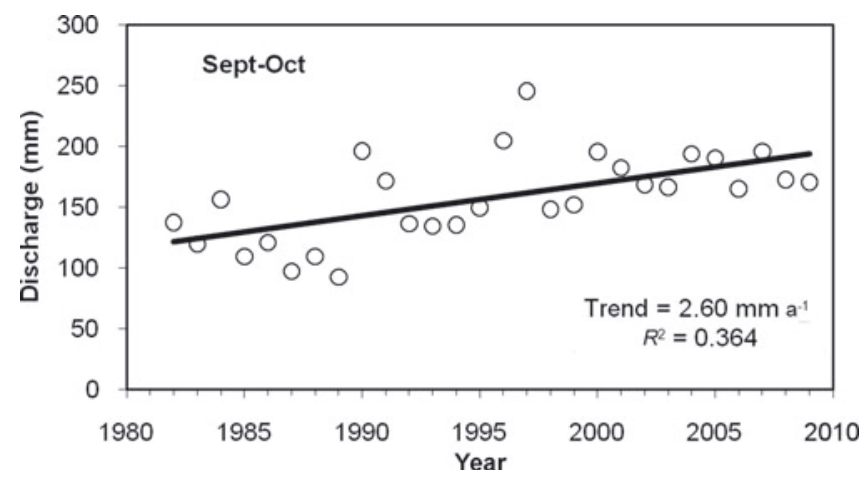

Fig. 3. September-October specific discharges $(\mathrm{mm})$ at Green Lake 4, 1982-2009. 
Table 1. September-October trends in discharge

\begin{tabular}{lcccccc}
\hline Basin & $\begin{array}{c}\text { Area Elevation } \\
\mathrm{km}^{2}\end{array}$ & $\mathrm{~m}$ & & Years & $\begin{array}{c}\text { Trend } \\
\mathrm{mm} \mathrm{a}^{-1}\end{array}$ & Correlation \\
& & & & & \\
\hline Navajo & 0.42 & 3730 & $1982-2009$ & $-1.6 \pm 1.2$ & $-0.17 \mathrm{NS}$ \\
Green Lake 5 & 1.35 & 3620 & $1982-2009$ & $2.1 \pm 0.5$ & $0.624^{\dagger}$ \\
Green Lake 4 & 2.21 & 3550 & $1982-2009$ & $2.6 \pm 0.7$ & $0.604^{\dagger}$ \\
Albion & 7.10 & 3250 & $1981-2009$ & $2.1 \pm 0.5$ & $0.648^{\dagger}$ \\
Martinelli & 0.08 & 3410 & $1982-2009$ & $-1.4 \pm 0.5$ & $-0.468^{*}$ \\
Middle Boulder & & & & & & \\
Creek & 93.8 & 2495 & $1980-2009$ & $-0.2 \pm 0.2$ & $-0.122 \mathrm{NS}$ \\
\hline
\end{tabular}

Note: Trends have been estimated by least-squares regression and are shown with a one standard error range: ${ }^{*} P<0.05,{ }^{\dagger} P<0.01$.

\section{HYDROCHEMICAL TRENDS}

The concentrations of major ions, $\mathrm{Si}$ and $\mathrm{pH}$ in the main stream of the upper Green Lakes basin and in the drainage from the rock glacier at Green Lake 5 during September and October are summarized in Table 2. With the exception of $\mathrm{NO}_{3}{ }^{-}$, they increase in the downstream direction, reflecting an increased soil and groundwater contribution to surface flows and the dilution of glacial meltwater at this time of year.

Over time, concentrations have also increased quite consistently since 1982 (Table 3). At Green Lakes 4 and 5, there is a marked increase in the flow-weighted concentrations of $\mathrm{Ca}^{2+}$ and $\mathrm{SO}_{4}{ }^{-}$, both of which are present in high concentration in the drainage from the rock glacier (Table 2). This increase occurred as a step change in 2000 (Fig. 4) and was associated with a period of drought and low snow accumulation in the basin (Williams and others, 2006). It is reflected in a marked increase in the S-ratio $\left(\mathrm{SO}_{4}{ }^{-} /\left(\mathrm{SO}_{4}{ }^{-}\right.\right.$ $\left.+\mathrm{HCO}_{3}{ }^{-}\right)$) in 2000. Prior to 2000, the mean ratio at Green Lake 4 was $0.43 \pm 0.02$, which increased to $0.65 \pm 0.03$ after that time. Further, it occurred at a time when $\mathrm{SO}_{4}{ }^{-}$ loading from the atmosphere to this part of the Front Range has been declining and $\mathrm{Ca}^{2+}$ loading has been about constant (records of atmospheric deposition on Niwot Ridge are available at http://nadp.sws.uiuc.edu/sites/sitinfo.asp? net $=$ NTN\&id $=$ CO02). The high concentrations of $\mathrm{Ca}^{2+}$ and $\mathrm{SO}_{4}{ }^{-}$in the rock glacier discharge have been interpreted previously as a response to the weathering of fresh mineral surfaces in the debris mantle (Williams and others, 2006) and suggest a change in the source of groundwater or its routing through the rock glacier. Upward trends in the

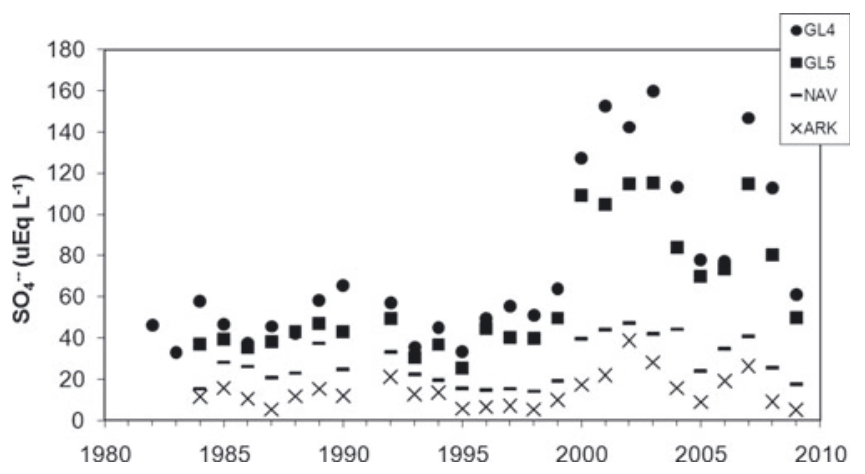

Fig. 4. Late-season $\mathrm{Ca}^{2+}$ and $\mathrm{SO}_{4}{ }^{-}$concentrations at four sites in the upper Green Lakes Valley, 1982-2009. Values shown are discharge-weighted concentration $\left(\mu \mathrm{Eq} \mathrm{L}^{-1}\right)$ of samples collected in September and October. Site identification: ARK, Arikaree Glacier; NAV, Navajo; GL5, outlet of Green Lake 5; GL4, outlet of Green Lake 4.

concentrations of other base cations, $\mathrm{NO}_{3}{ }^{-}$and $\mathrm{Si}$ over this period have been less marked and suggest a more gradual increase in autumn concentrations over much of the record (Table 3) rather than the step change suggested by the $\mathrm{Ca}^{2+}$ and $\mathrm{SO}_{4}{ }^{-}$record.

\section{DISCUSSION}

The increase in water yields at Green Lakes 4 and 5 has occurred during a time when September-October precipitation at the D-1 station on Niwot Ridge has shown a slight but non-significant declining trend (about $-0.6 \pm$ $1.3 \mathrm{~mm} \mathrm{a}^{-1}$ ). This clearly does not account for a change in streamflow of $2.6 \pm 0.7 \mathrm{~mm} \mathrm{a}^{-1}$ at Green Lake 4. September ablation rates on Arikaree Glacier at the head of the valley appear not to have changed significantly over the last 30 years (trend $=0.6 \pm 0.7 \mathrm{~mm}$ w.e. $\mathrm{a}^{-1}$ ). This would be equivalent to an increase in specific discharge at Green Lake 4 of $0.03 \mathrm{~mm} \mathrm{a}^{-1}$ and, even if increased by a factor of two to account for other surface ice sources within the basin, would amount to an increase in flow at Green Lake 4 of $<0.1 \mathrm{~mm} \mathrm{a}^{-1}$. Even including the errors in these estimates, this too is insufficient to account for the streamflow response. The best explanation for the remaining increase of about $2.5 \mathrm{~mm} \mathrm{a}^{-1}$ in the late-season streamflow at Green Lakes 4 and 5 seems to lie in a subsurface source, probably the melting of subsurface ice. If this is wet permafrost, its thawing would also provide a corresponding increase in groundwater

Table 2. September-October stream solute concentrations

\begin{tabular}{lrrrrr}
\hline Basin & $\begin{array}{c}\text { Cations } \\
\mu \mathrm{EqL}^{-1}\end{array}$ & $\begin{array}{c}\mathrm{SO}_{4}^{-} \\
\mu \mathrm{EqL}^{-1}\end{array}$ & $\begin{array}{c}\mathrm{NO}_{3}{ }^{-} \\
\mu \mathrm{EqL}^{-1}\end{array}$ & $\begin{array}{c}\mathrm{Si} \\
\mu \mathrm{mol} \mathrm{L}^{-1}\end{array}$ & \\
& & & & & \\
\hline Arikaree & 39.6 & 14.2 & 17.3 & 7.8 & 5.8 \\
Navajo & 75.2 & 27.6 & 33.7 & 32.6 & 5.0 \\
Green Lake 5 & 122.4 & 60.7 & 14.7 & 27.1 & 6.5 \\
Green Lake 4 & 135.4 & 73.9 & 9.3 & 28.1 & 6.6 \\
Rock Glacier* & 2303.7 & 2095.0 & 87.5 & 78.3 & 6.5 \\
\hline
\end{tabular}

Note: All concentrations are discharge-weighted means for 1982-2009, except for the Rock Glacier outflow $\left(^{*}\right)$ for which discharge estimates are not available and the record started in 1998.

Table 3. September-October trends in stream solute concentrations

\begin{tabular}{llllc}
\hline Basin & $\begin{array}{c}\text { Cations } \\
\mu \mathrm{EqLa}^{-1}\end{array}$ & $\begin{array}{c}\mathrm{SO}_{4}^{-} \\
\mu \mathrm{EqLa}^{-1}\end{array}$ & $\begin{array}{c}\mathrm{NO}_{3}{ }^{-} \\
\mu \mathrm{EqLa}^{-1}\end{array}$ & $\begin{array}{c}\mathrm{Si} \\
\mu \mathrm{mol} \mathrm{La}{ }^{-1}\end{array}$ \\
\hline Arikaree & $0.768 \mathrm{NS}$ & $0.026 \mathrm{NS}$ & $0.386 \mathrm{NS}$ & $-0.009 \mathrm{NS}$ \\
Navajo & $1.613^{*}$ & $0.469 \mathrm{NS}$ & $0.424 \mathrm{NS}$ & $1.334^{\dagger}$ \\
Green Lake 5 & $4.165^{\dagger}$ & $2.546^{\dagger}$ & $0.590^{*}$ & $0.882^{\dagger}$ \\
Green Lake 4 & $4.495^{\dagger}$ & $3.175^{\dagger}$ & $0.383^{*}$ & $0.626^{\dagger}$
\end{tabular}

Notes: All concentrations are discharge-weighted. Trends have been estimated by least-squares regression with $N$ between 25 and 28: $* P<0.05,{ }^{\dagger} P<0.01$. 
storage in the basin. Such an explanation is supported by the high $\mathrm{Ca}^{2+}$ and $\mathrm{SO}_{4}{ }^{-}$concentrations measured in the discharge from the active rock glacier on the north-facing slope of the basin at Green Lake 5. The thawing of permafrost may be explained by an increase in air temperatures and positive degree-days at the D-1 site which has occurred over the last few decades (Fig. 5). The effect of such an increase in summer air temperatures would not be effective in producing thaw at 2-3 $\mathrm{m}$ depth in the surficial debris until a lag of several months had passed, i.e. until the autumn when the active layer should be at its greatest thickness (Williams and Smith, 1989).

These empirical results suggest that more than half $\left(2.5 / 4.7 \mathrm{~mm} \mathrm{a}^{-1}\right)$ of the apparent increase in annual discharge and almost all $\left(2.5 / 2.6 \mathrm{~mm} \mathrm{a}^{-1}\right)$ of the increase in late-season streamflow from the alpine part of Green Lakes Valley in the last three decades may have been due to the melting of permafrost ice. Since we have no knowledge of the thickness of permafrost within the valley, or the volume of ice it contains, it is not possible to project this increase into the future. At present, the response at Green Lake 4 seems to derive from the north-facing wall of the valley adjacent to Green Lakes 4 and 5, where a number of springs continue to flow until late in the autumn in similar fashion to those of Loch Vale (Clow and others, 2003), and not from the highest elevations of the basin. An expansion to those elevations may occur in future, especially if the recent summer warming shown by an increasing trend of thawing degree-days continues. In that case, the augmented late-season flows from the alpine environment may continue for some decades. The fact that the increasing trend in late-season flows at Albion (300 m lower elevation) is of similar magnitude $\left(2.1 \pm 0.5 \mathrm{~mm} \mathrm{a}^{-1}\right.$; Table 1$)$ to that at Green Lake 4 suggests that equivalent sources occur in the valley below Green Lake 4. However, it should be noted that reservoir manipulation in the lower Green Lakes Valley, including a more frequent drawdown of Lake Albion in the autumns of the last 20 years, complicates the late-season hydrologic signal at Albion.

\section{CONCLUSION}

The relatively long and consistent record of empirical hydrologic and geochemical data suggests that flows in September and October from the alpine environment of the upper Green Lakes basin have increased by $2.6 \mathrm{~mm} \mathrm{a}^{-1}$ and that this has been associated with increased concentrations of solutes associated with groundwater. These changes are best explained as responses to the thawing of permafrost in the last 30 years. Until we have better knowledge of the extent, thickness and ice content of the permafrost in the basin and others like it, the continuation of this historical trend will remain unknown.

\section{ACKNOWLEDGEMENTS}

Research in the Green Lakes Valley has been supported by the US National Science Foundation through the Niwot Ridge LTER program (DEB-0423662) and the Boulder Creek Critical Zone Observatory (NSF-0724960). The assistance of field technicians from the Mountain Research Station, especially M. Losleben and K. Chowanski, and of a large number of field assistants and graduate students has ensured that hydrologic records have been maintained over 30 years. For most of that time, C. Seibold has been responsible for

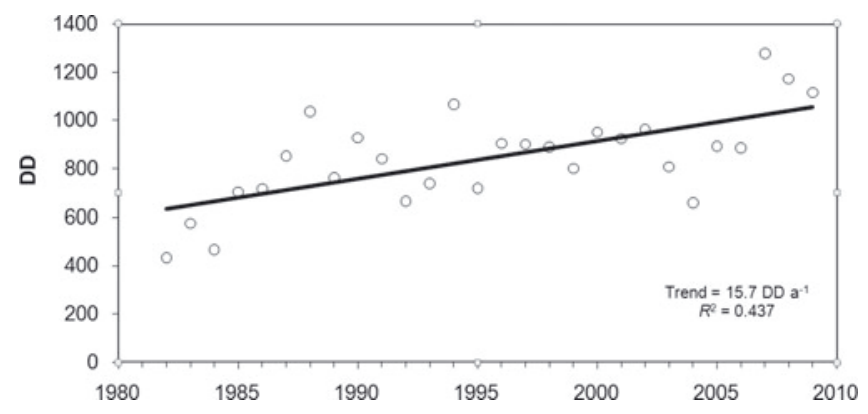

Fig. 5. The annual sum of positive degree-days (DD) based on mean daily air temperature at D-1 (3740 m elevation), Niwot Ridge, 1982-2009.

geochemical analyses for which I am most grateful. This contribution has benefited from discussions with S. Anderson and M. Williams. It has been much improved by the suggestions of two anonymous reviewers who provided detailed critical comments on an earlier version.

\section{REFERENCES}

Azócar, G.F. and A. Brenning. 2010. Hydrological and geomorphological significance of rock glaciers in the dry Andes, Chile $\left(27^{\circ}-33^{\circ}\right.$ S). Permafrost Periglac. Process., 21(1), 42-53.

Caine, N. 2001. Geomorphic systems of Green Lakes Valley. In Bowman, W.D. and T.R. Seastedt, eds. Structure and function of an Alpine ecosystem: Niwot Ridge, Colorado. New York, Oxford University Press.

Clow, D.W. 2010. Changes in the timing of snowmelt and streamflow in Colorado: a response to recent warming. J. Climate, 23(9), 2293-2306.

Clow, D.W., L. Schrott, R. Webb, D.H. Campbell, A. Torizzo and M. Dornblaser. 2003. Ground water occurrence and contributions to streamflow in an Alpine catchment, Colorado Front range. Ground Water, 41(7), 937-950.

Fischer, L., A. Kääb, C. Huggel and J. Noetzli. 2006. Geology, glacier retreat and permafrost degradation as controlling factors of slope instabilities in a high-mountain rock wall: the Monte Rosa east face. Natur. Hazards Earth Syst. Sci. (NHESS), 6(5), 761-772.

Gooseff, M.N., A. Balser, W.B. Bowden and J.B. Jones. 2009. Effects of hillslope thermokarst in Northern Alaska. Eos, 90(4), 29.

Harris, C. and 21 others. 2009. Permafrost and climate in Europe: monitoring and modelling thermal, geomorphological and geotechnical responses. Earth-Sci. Rev., 92(3-4), 117-171.

Hood, E.W., M.W. Williams and N. Caine. 2003. Landscape controls on organic and inorganic nitrogen leaching across an alpine/subalpine ecotone, Green Lakes Valley, Colorado Front Range. Ecosystems, 6(1), 31-45.

Huggel, C. and 8 others. 2010. Recent and future warm extreme events and high-mountain slope stability. Philos. Trans. R. Soc. London, Ser. A, 368(1919), 2435-2459.

Ives, J.D. 1973. Permafrost and its relationship to other environmental parameters in a mid-latitude setting, Front Range, Colorado Rocky Mountains. In Permafrost: the North American Contributions to the 2nd International Permafrost Conference. Washington DC, National Academy of Sciences, 121-125.

Janke, J.R. 2005. The occurrence of alpine permafrost in the Front Range of Colorado. Geomorphology, 67(3-4), 375-389.

Keller, K., J.D. Blum and G.W. Kling. 2010. Stream geochemistry as an indicator of increasing permafrost thaw depth in an Arctic watershed. Chemical Geol., 273(1-2), 76-81.

Leopold, M., D. Dethier, J. Völkel, T. Raab, T. Corson Rikert and N. Caine. 2008. Using geophysical methods to study the shallow subsurface of a sensitive Alpine environment, Niwot Ridge, 
Colorado Front Range, USA. Arct. Antarct. Alp. Res., 40(3), 519-530.

Leopold, M., M. Williams, N. Caine, J. Völkel and D. Dethier. In press. The internal structure and hydrologic flowpaths of the Green Lake 5 rock glacier, Colorado Front Range, USA. Permafrost Periglac. Process, n/a. doi: 10.1002/ppp.706.

Rowland, J.C. and 16 others. 2010. Arctic landscapes in transition: responses to thawing permafrost. EOS, 91(26), 229-236.

Stewart, I.T., D.R. Cayan and M.D. Dettinger. 2004. Changes in snowmelt runoff timing in western North America under a 'business as usual' climate change scenario. Climatic Change, 62(1-3), 217-232.

Stewart, I.T., D.R. Cayan and M.D. Dettinger. 2005. Changes toward earlier streamflow timing across western North America. J. Climate, 18(8), 1136-1155.
Williams, M.W. and N. Caine. 2001. Hydrology and hydrochemistry. In Bowman, W.D. and T.R. Seastedt, eds. Structure and function of an Alpine ecosystem. New York, Oxford University Press, 75-96.

Williams, M.W., M. Knauf, N. Caine, F. Liu and P.L. Verplanck. 2006. Geochemistry and source waters of rock glacier outflow, Colorado Front Range. Permafrost Periglac. Process., 17(1), 13-33.

Williams, M.W., M. Knauf, R. Cory, N. Caine and F. Liu. 2007. Nitrate content and potential microbial signature of rock glacier outflow, Colorado Front Range. Earth Surf. Process. Landf., 32(7), 1032-1047.

Williams, P.J. and M.W. Smith. 1989. The frozen Earth: fundamentals of geocryology. Cambridge, Cambridge University Press. 